\title{
Effect of Fertilizer Rate on the Yield And Yield Component of Sesame(Sesamumindicum) in Moisture Stress of Eastern Harerghe Zone
}

\author{
Habte Berhanu Umata* and Adugna Hunduma Dabalo \\ Fadis Agricultural Research Center, Ethiopia \\ Submission: June 08, 2016; Published: July 19, 2017 \\ "Corresponding author: HHabte Berhanu Umata, Plant Breeder, Fadis Agricultural Research Center, Harar, P.O.Box:904, Ethiopia, \\ Tel: +251256667549; Fax: +251256667551; Email: habtiyebirish@gmail.com
}

\begin{abstract}
Field trials on sesame were conducted at the Fadis Agricultural Research Station during the 2014 and 2015 cropping seasons to determine the optimal rate of Nitrogen(UREA) fertilizer and Phosphorus(DAP) for sesame production. The experiment consisted of four rates of Nitrogen in the form of UREA $\left(0,40,60, \& 80 \mathrm{~kg} \mathrm{ha}^{-1}\right)$, and four levels of Phosphorus in the form of DAP $\left(0,10,20 \& 30 \mathrm{~kg} \mathrm{ha}^{-1}\right)$ applied to the treatments. The sixteen treatment combinations were laid out in a RCBD design with three replications. Yield of Sesame and yield related components were showing significant difference ( $\mathrm{p}<0.05)$. Analysis of variances showed that grain yield, number of capsule per plant, number of seeds per capsule and number of branching per plant was significant differences at $(\mathrm{P}<0.05)$ both at Fadis and Erer of study areas. Grain yield increases from $518.1 \mathrm{~kg} / \mathrm{ha}$ to $891 \mathrm{~kg} / \mathrm{ha}$ as N increases from 0 (control) to $24.6 \mathrm{kgN}$ (60kgDAP @ 30kgUREA).
\end{abstract}

Keywords: Nitrogen; Phosphorus; Plant nutrient; Sesame

\section{Introduction}

Sesame (Sesamumindicum) is grown in areas with annual rainfall of $625-1100 \mathrm{~mm}$ and temperature of $>27{ }^{\circ} \mathrm{C}$. The crop is tolerant to drought, but not to water logging and excessive rainfall [1].

In Ethiopia, the production of sesame is both by small and large scale farmers; and it is an important crop and export commodity. The total area, production and productivity during 2013 were 0.299 million ha, 0.220 million tones and $0.735 \mathrm{tha}^{-1}$, respectively; and the total area and production were increased by $61.23 \%$ and $17.91 \%$, respectively, while the total productivity was decreased by $27.23 \%$ when compared with in 2008 [2,3]. Sesame ranks first in total area and production from oil crops during 2013; and Tigray, Oromia, Amhara and BenshangulGumuz regions are the major producers in Ethiopia.

Since sesame contributes more than $80 \%$ of the export earning of oil seeds it has become the $2^{\text {nd }}$ foreign currency earning crop after coffee. Ethiopian sesame seed market covers quiet a wide range of countries all over the world. The growing demand in the world market and the available capacity to expand sesame production could contribute to the economic growth of Ethiopia .The oilseeds sector is one of Ethiopia's fastest growing and important sectors, both in terms of its foreign exchange earnings and as a main source of income for over three million Ethiopians. Study reports indicate that Ethiopia is among the six producers of sesame seed, linseed and niger seed in the world [4]. The major sesame seed producing regions are situated in the North West and South West Ethiopian in Humera, North Gondar and Wollega [2,5]. For instance, the main source of farmers' income in western Tigray was sesame sales.

Sesame is deep rooted and will scavenge for fertility below the wheat root zone, but that only works once. The sesame will strip that lower reserve, and the fertility will not be available for future sesame crops. The rates vary with soils, rainfall patterns, and local farming practices. There is little work on PK rates and most farmers use the cotton recommendations for their soils [6]. Work has shown that N P is critical for high yields, particularly in acidic soils. When having to apply all of the fertility up front, a slow releasing fertilizer should be used. Using a full rate of anhydrous ammonia up front has not worked because it is not available at the critical time when the plants are producing seeds.

At present, the Ethiopian government devotes considerable resources to research and extension in view of encouraging small 
scale farmers to increase their productivity and to be focused them on international high market demanded crops to increase export earnings of the country. One of such crop is improved sesame. Sesame is one of the oil crops grown in the area next to groundnut in the study areas. In the last year (the second year cropping the study) Participatory Agricultural Production Constraint Analysis survey was taken and they underline the constraints based on the assessment taken in description of AGP-II districts in the study areas. Farmers from the assessment description of AGP-II districts noted that poor soil fertility is the number one of production constraints in the area.

The major constraints in sesame production worldwide are lack of wider adapting cultivars, shattering of capsules at maturity, nonsynchronous maturity, poor stand establishment, lack of fertilizer responses, profuse branching, and low harvest index [7]. Thus this experiment was aimed to solve the response of fertilizer rate for sesame in moisture stress of eastern hararghe (Table 1- 3).

Table 1: The mean of sesame yield and yield component parameters at Fadis and Erer 2014 production year.

\begin{tabular}{|c|c|c|c|c|c|c|c|c|}
\hline \multirow[t]{2}{*}{ Treatment Name } & \multicolumn{4}{|c|}{ Grain Yield and Yield Component at Fadis } & \multicolumn{4}{|c|}{ Grain Yield and Yield Component at Fadis } \\
\hline & $\begin{array}{c}\text { Grain Yield } \\
\mathrm{Kg} / \mathrm{Ha}\end{array}$ & $\begin{array}{l}\text { No Branches } \\
\text { /Plant }\end{array}$ & Pod /Plant & Seed/Pod & $\begin{array}{c}\text { Grain Yield/ } \\
\text { Kg }\end{array}$ & $\begin{array}{l}\text { No Branches } \\
\text { /Plant }\end{array}$ & Pod/Plant & Seed/Pod \\
\hline 0DAP@0UREA & $525 c$ & $14.33 \mathrm{~cd}$ & 57.67 & 31.67 & $616.7 \mathrm{c}$ & $15.00 \mathrm{bc}$ & $56.33 \mathrm{ab}$ & 28.67 \\
\hline 0DAP@10UREA & $680.6 \mathrm{bc}$ & $17.67 \mathrm{bcd}$ & 66.33 & 34 & $720.8 \mathrm{bc}$ & $21.67 \mathrm{ab}$ & $55.67 \mathrm{ab}$ & 31 \\
\hline 0DAP@20UREA & $628.9 b c$ & $18.33 \mathrm{bcd}$ & 47.33 & 33 & $763.9 \mathrm{bc}$ & $19.33 \mathrm{ab}$ & $44.67 \mathrm{~b}$ & 30 \\
\hline 0DAP@30UREA & $522.2 \mathrm{c}$ & $16.67 \mathrm{abc}$ & 57 & 32.33 & $648.6 c$ & $20.67 \mathrm{ab}$ & $6.00 \mathrm{ab}$ & 29.33 \\
\hline 40DAP@OUREA & 759.7ab & $12.67 \mathrm{~cd}$ & 58 & 33.33 & $754.2 \mathrm{bc}$ & $16.67 \mathrm{bc}$ & $67.33 \mathrm{a}$ & 30.33 \\
\hline 40DAP@10UREA & $754.4 \mathrm{ab}$ & $11.33 \mathrm{~cd}$ & 56.67 & 31.67 & $697.2 \mathrm{bc}$ & $15.33 \mathrm{bc}$ & $55.67 \mathrm{ab}$ & 28.67 \\
\hline 40DAP@20UREA & 731.9abc & $23.33 \mathrm{ab}$ & 56.67 & 32.67 & $847.2 \mathrm{~b}$ & $20.00 \mathrm{abc}$ & $55.67 \mathrm{ab}$ & 29.67 \\
\hline 40DAP@30UREA & $641.7 \mathrm{bc}$ & $11.67 \mathrm{~cd}$ & 57 & 33 & $625.0 \mathrm{c}$ & $15.67 \mathrm{bc}$ & $56.33 \mathrm{ab}$ & 30 \\
\hline 60DAP@0UREA & $709.4 \mathrm{abc}$ & $8.67 d$ & 67 & 32.33 & $679.2 \mathrm{bc}$ & $16.67 \mathrm{bc}$ & $56.00 \mathrm{ab}$ & 29.33 \\
\hline 60DAP@10UREA & $794.2 \mathrm{ab}$ & $18.33 \mathrm{bcd}$ & 57 & 32 & $630.6 c$ & $18.33 \mathrm{bc}$ & $56.67 \mathrm{ab}$ & 29 \\
\hline 60DAP@20UREA & 759.7ab & $12.67 \mathrm{~cd}$ & 56.67 & 33 & $675.0 \mathrm{bc}$ & $16.67 \mathrm{bc}$ & $55.67 \mathrm{ab}$ & 30 \\
\hline 60DAP@30UREA & $867.8 \mathrm{a}$ & $18.33 a$ & 67.33 & 31.67 & $912.5 \mathrm{a}$ & $22.33 a$ & $56.00 \mathrm{ab}$ & 28.67 \\
\hline 80DAP@0UREA & $610.8 \mathrm{bc}$ & 13.33abcd & 67.33 & 32.67 & $673.6 \mathrm{bc}$ & $17.33 \mathrm{bc}$ & $67.00 \mathrm{a}$ & 29.67 \\
\hline 80DAP@10UREA & $686.1 \mathrm{abc}$ & 12.33abcd & 56.67 & 32.67 & $683.3 \mathrm{bc}$ & $16.33 \mathrm{bc}$ & $56.00 \mathrm{ab}$ & 29.67 \\
\hline 80DAP@20UREA & $697.2 \mathrm{abc}$ & $9 \mathrm{bcd}$ & 57 & 32.67 & $691.7 \mathrm{bc}$ & $13 c$ & $44.67 \mathrm{~b}$ & 29.67 \\
\hline 80DAP@30UREA & $818.1 \mathrm{ab}$ & $8 \mathrm{bcd}$ & 57 & 33.67 & $677.8 \mathrm{bc}$ & $12 c$ & $55.67 \mathrm{ab}$ & 30.67 \\
\hline CV (\%) & 15.4 & 11.4 & 12.3 & 4.4 & 18.8 & 10.9 & 19.9 & 4.9 \\
\hline L.S.D & 181.34 & 5 & Ns & ns & 162.53 & 4.96 & 11.94 & Ns \\
\hline P Value & * & * & & & * & * & * & \\
\hline
\end{tabular}




\section{Agricultural Research \& Technology: Open Access Journal}

Table 2: The effect fertilizer rate on sesame yield and yield component at Fadisand Erer in 2015.

\begin{tabular}{|c|c|c|c|c|c|c|c|c|}
\hline \multirow[t]{2}{*}{ Treatment Name } & \multicolumn{4}{|c|}{ Grain Yield and Yield Component at Fadis } & \multicolumn{4}{|c|}{ Grain Yield and Yield Component at Erer } \\
\hline & $\begin{array}{c}\text { Grain } \\
\text { Yield/Kg }\end{array}$ & $\begin{array}{l}\text { No Branches } \\
\text { /Plant }\end{array}$ & Pod /Plant & Seed/Pod & $\begin{array}{c}\text { Grain } \\
\text { Yield/Kg }\end{array}$ & $\begin{array}{c}\text { No Branches/ } \\
\text { Plant }\end{array}$ & Pod/Plant & Seed/Pod \\
\hline 0DAP@0UREA & $598.6 b$ & $7.47 \mathrm{bc}$ & $65.5 \mathrm{bc}$ & $44.33 b$ & $652.5 d$ & $5.67 \mathrm{c}$ & $69.67 \mathrm{ab}$ & 46 \\
\hline 0DAP@10UREA & $664.4 \mathrm{~b}$ & $6.00 \mathrm{c}$ & $56.00 \mathrm{c}$ & $53.00 \mathrm{ab}$ & $746.1 c$ & $6.33 c$ & $64.33 \mathrm{ab}$ & 42 \\
\hline 0DAP@20UREA & $715 a b$ & $6.33 c$ & $56.33 c$ & $44.00 \mathrm{~b}$ & $772.2 \mathrm{bc}$ & $6.33 c$ & $62.33 \mathrm{ab}$ & 45.33 \\
\hline 0DAP@30UREA & $650.8 b$ & $4.33 c$ & $49.33 c$ & $54.00 \mathrm{ab}$ & $702.8 c$ & $6.00 \mathrm{c}$ & $61.00 \mathrm{ab}$ & 44 \\
\hline 40DAP@0UREA & $700.6 \mathrm{~b}$ & $5.83 \mathrm{bc}$ & $59.83 \mathrm{bc}$ & $55.67 \mathrm{ab}$ & $756.9 \mathrm{c}$ & $7.67 \mathrm{~b}$ & 73.67ab & 44.67 \\
\hline 40DAP@10UREA & $886.7 \mathrm{ab}$ & $6.5 \mathrm{bc}$ & $87.17 \mathrm{ab}$ & $53.67 \mathrm{ab}$ & $748.9 c$ & $7.00 \mathrm{~b}$ & $72.00 \mathrm{ab}$ & 44.67 \\
\hline 40DAP@20UREA & 865.3ab & $7.53 \mathrm{~b}$ & 89.83ab & $57.00 \mathrm{ab}$ & $807.5 \mathrm{ab}$ & $7.33 \mathrm{~b}$ & 71.33ab & 46.67 \\
\hline 40DAP@30UREA & $804.2 \mathrm{ab}$ & $6.83 c$ & $56.83 c$ & $44.33 \mathrm{~b}$ & $799.7 b$ & $6.67 \mathrm{~b}$ & $62.67 \mathrm{ab}$ & 44 \\
\hline 60DAP@10UREA & $938.9 a$ & $6.33 \mathrm{bc}$ & $60.33 \mathrm{bc}$ & $55.67 \mathrm{ab}$ & $760.6 c$ & $9.00 \mathrm{a}$ & $69.00 \mathrm{ab}$ & 46.67 \\
\hline 60DAP@20UREA & $741.1 \mathrm{ab}$ & $12.43 \mathrm{ab}$ & $59.17 \mathrm{bc}$ & 49.33ab & $780.0 \mathrm{~b}$ & $7.67 \mathrm{~b}$ & $59.67 \mathrm{~b}$ & 44 \\
\hline 60DAP@30UREA & $964.2 \mathrm{a}$ & $15.17 \mathrm{a}$ & $96.43 a$ & $61.00 \mathrm{ab}$ & $897.2 \mathrm{a}$ & $9.67 a$ & $74.67 \mathrm{a}$ & 44 \\
\hline 80DAP@0UREA & 898.6ab & $5.33 c$ & $50.33 c$ & $53.67 \mathrm{ab}$ & $653.6 \mathrm{~d}$ & $6.67 \mathrm{~b}$ & $64.67 \mathrm{ab}$ & 46 \\
\hline 80DAP@10UREA & $672.5 \mathrm{ab}$ & $7.00 \mathrm{bc}$ & $75.00 \mathrm{abc}$ & 48.33ab & $643.9 \mathrm{~d}$ & $5.67 c$ & $59.67 \mathrm{~b}$ & 44 \\
\hline 80DAP@20UREA & $891.4 \mathrm{ab}$ & $5.17 \mathrm{c}$ & $52.17 \mathrm{c}$ & 49.67ab & $774.2 \mathrm{bc}$ & $6.00 \mathrm{c}$ & $66.00 \mathrm{ab}$ & 45.33 \\
\hline 80DAP@30UREA & 842.8ab & $6.50 \mathrm{bc}$ & $65.50 \mathrm{bc}$ & $47.00 \mathrm{ab}$ & $646.1 \mathrm{~d}$ & $7.33 \mathrm{~b}$ & 74.33a & 43.33 \\
\hline $\mathrm{CV}(\%)$ & 19.1 & 25.8 & 25.8 & 13.1 & 16.7 & 7.3 & 7.3 & 6.4 \\
\hline L.S.D & 269.7 & 7.6 & 27.6 & 11.42 & 170.68 & 1.33 & 11.7 & ns \\
\hline
\end{tabular}

Table 3: The overall mean interaction of sesame yield of the two locations (Erer and Fadis) in 2014 \& 2015.

\begin{tabular}{|c|c|c|c|c|}
\hline Treatment Name & Grain Yield/Kg & No Branches/Plant & Pod/Plant & Seed/Pod \\
\hline 0DAP@0UREA & $518.1 d$ & $20 \mathrm{~b}$ & $48.21 b$ & 41.58 \\
\hline 0DAP@10UREA & $703 \mathrm{bc}$ & $17.42 b$ & $58.21 \mathrm{ab}$ & 40 \\
\hline 0DAP@20UREA & $670 \mathrm{bc}$ & $17.33 \mathrm{~b}$ & $57.50 \mathrm{ab}$ & 38.08 \\
\hline 0DAP@30UREA & $651.6 b c$ & $19.42 b$ & $57.75 \mathrm{ab}$ & 39.92 \\
\hline 40DAP@0UREA & $692.8 \mathrm{bc}$ & $15.71 b$ & $57.83 \mathrm{ab}$ & 41 \\
\hline 40DAP@10UREA & $696.9 \mathrm{bc}$ & $19.21 b$ & $57.46 \mathrm{ab}$ & 39.67 \\
\hline 40DAP@20UREA & $763 b$ & $23.62 \mathrm{a}$ & $57.04 \mathrm{~b}$ & 41.5 \\
\hline 40DAP@30UREA & $617.6 \mathrm{~cd}$ & $14.21 \mathrm{c}$ & $57.67 \mathrm{ab}$ & 37.83 \\
\hline 60DAP@0UREA & $617.7 \mathrm{~cd}$ & $15.02 \mathrm{c}$ & $58.00 \mathrm{ab}$ & 41.42 \\
\hline 60DAP@10UREA & $652.2 \mathrm{bc}$ & $20 \mathrm{~b}$ & $58.58 \mathrm{ab}$ & 40.83 \\
\hline 60DAP@20UREA & $639 c$ & $14.54 \mathrm{c}$ & $58.21 \mathrm{ab}$ & 39.08 \\
\hline 60DAP@30UREA & $891 a$ & $28.71 \mathrm{a}$ & $68.67 a$ & 38.83 \\
\hline 80DAP@0UREA & $659.2 b c$ & $18.92 b$ & $58.54 \mathrm{ab}$ & 40.5 \\
\hline 80DAP@10UREA & $614 \mathrm{~cd}$ & $13.33 c$ & $58.33 \mathrm{ab}$ & 38.67 \\
\hline 80DAP@20UREA & $663.6 \mathrm{bc}$ & $17.54 \mathrm{~b}$ & $57.58 \mathrm{ab}$ & 39.33 \\
\hline 80DAP@30UREA & $693.7 \mathrm{bc}$ & $12.46 \mathrm{c}$ & $58.17 \mathrm{ab}$ & 38.67 \\
\hline CV (\%) & 18.3 & 13.6 & 19.8 & 9.6 \\
\hline L.S.D & 126 & 3.62 & 11.28 & ns \\
\hline
\end{tabular}


Materials and Methods

\section{Description of experimental site}

The study was conducted under rain fed conditions at two location (Fadis; Boko site) and Erer sub-site. Fadis, is located at the latitude of $9^{\circ} 07^{\prime}$ north and longitude of $42^{\circ} 04^{\prime}$ east, in the middle and lowland areas and at the altitude of 1702 meters above sea level, with a prevalence of lowlands. The area is situated at the distance of about $24 \mathrm{~km}$ from Harar town in the southerly direction. The experimental area is characterized as lowland climate. The mean rainfall is about $860.4 \mathrm{~mm}$ for the last five years. The rainfall has a bimodal distribution pattern with heavy rains from April to June and long and erratic rains from August to October. The mean maximum and minimum annual temperature are $28.2{ }^{\circ} \mathrm{C}$ and $10.2{ }^{\circ} \mathrm{C}$, respectively, for the last five years (Fadis Agriculture Research Center Metrological Station) (Appendix. 1 \& 2).

\section{Appendix 1: Eight (8) years precipitation (Rain fall) $\mathrm{mm}$ data.}

\begin{tabular}{|c|c|c|c|c|c|c|c|c|}
\hline & \multicolumn{9}{|c|}{ Years } \\
\hline Months & $\mathbf{2 0 0 9}$ & $\mathbf{2 0 1 0}$ & $\mathbf{2 0 1 1}$ & $\mathbf{2 0 1 2}$ & $\mathbf{2 0 1 3}$ & $\mathbf{2 0 1 4}$ & $\mathbf{2 0 1 5}$ & $\mathbf{2 0 1 6}$ \\
\hline January & 0 & 0 & 0 & 0 & 16.8 & 0 & 25.5 & 4.7 \\
\hline February & 72.1 & 61.5 & 9.4 & 0 & 0 & 1.2 & 4.9 & 0 \\
\hline March & 23.4 & 223.5 & 3.2 & 4.4 & 190.3 & 95.6 & 66.0 & 26.4 \\
\hline April & 111.5 & 187.1 & 25.7 & 190.6 & 147.2 & 108.7 & 29.6 & 239.5 \\
\hline May & 145.2 & 199.5 & 226.0 & 124.5 & 60.6 & 117.7 & 161.7 & 170.55 \\
\hline June & 68.8 & 22.5 & 67.7 & 69.4 & 46.3 & 67.5 & 132.3 & 94.8 \\
\hline July & 112.2 & 122.1 & 60.8 & 95.9 & 96.6 & 66.5 & 44.9 & 96.3 \\
\hline August & 109.3 & 119.7 & 144.4 & 164.9 & 59.3 & 201.4 & 106.3 & 56.8 \\
\hline September & 115.8 & 136.9 & 224.9 & 220.25 & 126.4 & 94.1 & 95.5 & 100.0 \\
\hline October & 183.5 & 11.4 & 3.4 & 3.9 & 116.3 & 166.5 & 25.2 & 36.3 \\
\hline November & 13.8 & 18.7 & 25.5 & 0.6 & 66.7 & 17.9 & 22.4 & 48.7 \\
\hline December & 0.9 & 0 & 0 & 2.7 & 0 & 0 & 10.6 & 9.7 \\
\hline
\end{tabular}

Appendix 2: Average of 8 years mean of maximum temperature of Fadis $\left({ }^{\circ} \mathrm{C}\right)$.

\begin{tabular}{|c|c|c|c|c|c|c|c|c|c|c|c|c|c|c|c|c|}
\hline \multirow{3}{*}{$\begin{array}{l}\text { Months } \\
\text { January }\end{array}$} & \multicolumn{16}{|c|}{ Years } \\
\hline & \multicolumn{2}{|c|}{2009} & \multicolumn{2}{|c|}{2010} & \multicolumn{2}{|c|}{2011} & \multicolumn{2}{|c|}{2012} & \multicolumn{2}{|c|}{2013} & \multicolumn{2}{|c|}{2014} & \multicolumn{2}{|c|}{2015} & \multicolumn{2}{|c|}{2016} \\
\hline & Max & Min & Max & Min & Max & Min & Max & Min & Max & Min & Max & Min & Max & Min & Max & Min \\
\hline & 28.2 & 11.1 & 27.9 & 11.3 & 28.5 & 8.4 & 28.6 & 8.2 & 28.9 & 7.1 & 28.8 & 5.8 & 28.5 & 6.3 & 28.9 & 9.4 \\
\hline February & 27.8 & 12.1 & 28.0 & 13.6 & 30.0 & 9.3 & 31.0 & 7.2 & 31.0 & 7.1 & 30.1 & 8.3 & 31.4 & 6.5 & 31.5 & 8.6 \\
\hline March & 28.1 & 12.4 & 27.3 & 13.5 & 30.8 & 10.5 & 29.4 & 9.3 & 29.4 & 9.8 & 30.3 & 9.5 & 31.4 & 8.7 & 33.6 & 11.4 \\
\hline April & 27.9 & 13.3 & 27.2 & 14.2 & 31.0 & 12.5 & 27.6 & 11.4 & 28.0 & 11.2 & 28.4 & 10.6 & 31.6 & 9.6 & 28.5 & 12.2 \\
\hline May & 27.3 & 13.8 & 27.4 & 15.0 & 27.5 & 12.0 & 27.8 & 11.1 & 28.0 & 10.3 & 27.5 & 10.6 & 29.2 & 10.6 & 28.0 & 11.3 \\
\hline June & 28.7 & 13.7 & 27.0 & 14.5 & 26.3 & 12.5 & 27.2 & 10.4 & 27.5 & 10.2 & 28.9 & 9.8 & 28.4 & 10.8 & 27.2 & 10.6 \\
\hline July & 27.8 & 13.9 & 24.6 & 12.3 & 26.0 & 11.8 & 25.2 & 10.9 & 24.8 & 10.2 & 28.6 & 10.3 & 28.3 & 10.3 & 26.9 & 10.9 \\
\hline August & 28.7 & 14.3 & 25.5 & 12.9 & 25.7 & 12.0 & 26.7 & 10.2 & 26.3 & 9.9 & 27.5 & 9.7 & 28.1 & 10.6 & 27.3 & 11.0 \\
\hline September & 27.8 & 14.0 & 26.6 & 12.0 & 25.9 & 11.2 & 26.5 & 10.3 & 27.9 & 9.2 & 26.8 & 9.7 & 29.7 & 10.4 & 28.8 & 10.7 \\
\hline October & 26.9 & 15.8 & 28.6 & 9.8 & 28.5 & 8.2 & 27.9 & 6.9 & 27.8 & 8.3 & 27.4 & 7.8 & 30.9 & 9.4 & 28.9 & 10.0 \\
\hline November & 27.8 & 10.3 & 27.7 & 9.1 & 28.1 & 8.8 & 28.8 & 6.9 & 27.2 & 7.3 & 28.5 & 7.1 & 30.0 & 8.7 & 29.2 & 8.2 \\
\hline December & 27.3 & 11.9 & 27.3 & 7.5 & 27.1 & 7.0 & 29.7 & 6.5 & 26.9 & 4.9 & 27.8 & 5.6 & 29.3 & 8.8 & 29.1 & 7.9 \\
\hline
\end{tabular}


The second experimental area of our experiment Erer Subsite is located at Erer valley of Babile Wored as, which is located at $34 \mathrm{~km}$ from Harar city in eastern direction. The area receives an average annual rainfall of about $400-600 \mathrm{~mm}$. The altitude of the area lay between 950-2000 meters at sea level. And the experimental area was extremely lowland which is suitable for the production of sesame.

\section{Data to be collected}

All quantitative data (number of branches per plant, number of capsule per plant, number of seed per capsule, seed yield per hectare $(\mathrm{kg} / \mathrm{ha})$ ) were collected.

\section{Data management and statistical analysis}

The experimental plots were laid out in Randomized Complete Block Design (RCBD) with three replications.

The treatments were inserted randomly to each block. All collected data were entered into computer and analyzed using GenSTAT statistical software package and mean values or Least Significant Differences (LSD) were compared using the procedures of Duncan's at the $5 \%$ level of significance.

\section{Description of experimental materials}

This experiment were planted at Fadis station and Erer sub-site with main objectives of evaluating, identifying and, recommending the best fertilizer rate that maximum yield with the best performance of sesame at lowland and mid-altitude of Eastern Harerghe area.The treatments consisted of a sesame variety (Tate), four nitrogen levels $(0,10,20$ and $30 \mathrm{kgN} / \mathrm{ha})$ in the form of UREA and four phosphorus levels $((0,40,60$ and $80 \mathrm{~kg})$ P205/ha) in the form of DAP. The treatments were arranged in a Randomized complete block design with three replications. The experimental field was ploughed, harrowed and ridged $40 \mathrm{~cm}$ apart. A mixture of one part of sesame Seed and two parts of course river sand were sown manually at a shallow depth of about $1 \mathrm{~cm}$, by dibbling. The emerged plants were thinned to one plant per stand at two weeks after sowing at an intra-row spacing of $10 \mathrm{~cm}$. This arrangement gave population densities of 250,000 plants per hectare. Phosphorus fertilizer was applied at planting to all the plots at the rate of $0 \mathrm{~kg}, 40 \mathrm{~kg}, 60 \mathrm{~kg}$ and $80 \mathrm{~kg}$ in the form of DAP. Nitrogen fertilizer was applied at two and six weeks after sowing in two equal split doses at the rates of $((0 \mathrm{~kg}, 10 \mathrm{~kg}$, $20 \mathrm{~kg}$ and $30 \mathrm{~kg}) \mathrm{N} / \mathrm{ha}$ ) as per treatments using Urea $(46 \% \mathrm{~N})$. All agronomic practices were equally applied as per recommended.

\section{Experimental Procedures}

The experimental field was cultivated to a depth of $25-30 \mathrm{~cm}$ by a tractor. The experimental plots were harrowed to a fine tilth manually before planting. The land was leveled well. Seeds were sown on well prepared experimental plot on 28June 2014 and 27 June 2015 of cropping season. Sesame seeds were carefully sown at $1 \mathrm{~cm}$ depth in the prepared plots with $4.2 \mathrm{mx} 3 \mathrm{~m}$ dimensions to accommodate 180 plants per plot at a recommended spacing of $40 \mathrm{~cm} \times 10 \mathrm{~cm}$ between rows and plants, respectively. Standard agronomic practices such as weeding, cultivation, fertilizer application (accordingly the rate of treatments) and tinning were carried out uniformly during the growing season for all plots. Starting from land preparation to harvesting and storing the seeds carefully attention was given accordingly to follow the all data collection; recording and registering (entering) in to computer were done appropriately.

\section{Results and Discussion}

The experiment was conducted at two locations (Fadis station and Erer sub-station) for two years (2014 \& 2015) with theobjective of evaluating the effect of fertilizer rate on the yield and yield component of sesame (Tate) [8]. Showed that different levels of nitrogen and phosphorus significantly $(\mathrm{P}<0.05)$ affected almost all the growth and yield attributes of sesame varieties, particularly seed yield. Maximum plant height $(\mathrm{cm})$, branches plant-1, capsules plant-1, seeds capsule-1, seed weight plant-1 (g), seed index (1000 seed weight, g) and seed yield $(774.17 \mathrm{~kg}$. $\mathrm{ha}^{-1}$ ) were recorded in NP @ 70-70 kg $\cdot \mathrm{ha}^{-1}$, followedby NP @ 70-50kg.ha ${ }^{-1}$, whereas minimum growth and yield parameters were noted in No fertilizer (Control). Similarly in our findings application of NP rates show significant effect $(\mathrm{P} \leq 0.05)$ on number of branching per plant, number of capsule per plants, number of seeds per capsule and grain yield at harvesting time during 2014 at Fadis and Erer (Table 1). The number of branching per plant increased from 14.33 to 18.33 as the application of fertilizer increased from $0 \mathrm{~kg}$ (control) to 24.6kg (60DAP@30UREA) of nitrogen and number of branching decreases as $\mathrm{N}$ rate increases. As $\mathrm{N}$ rate increases the plant were elongated rather than branching. In 2015, similarly significant difference $(\mathrm{P} \leq 0.05)$ was observed on number of primary branches per plant because of application of Nitrogen and Phosphorus. At both location (Fadis station and Erer sub-station) there were significant difference on grain yield. But the yield obtained was quite far for the location. This might be influenced by the environment which could have counted for the fewer branches in sown crops because of the change in the environmental condition that forces the crop to reduce vegetative growth and commence reproductive phase as reported by [9]. In 2015 because of the occurrence of El-Nino the eastern parts of Ethiopia is highly affected. Thus why the experimental plot is also affected. Branching in crops has been reported by [10] to be enhanced by favorable growth condition as obtained in most cases at early part of the season when rains are fully established.

[11] reported that Interaction between nitrogen and phosphorus showed maximum number of pods/plant (70) at $100: 80 \mathrm{~kg} \mathrm{~N}: \mathrm{P} / \mathrm{ha}$, while minimum number of pods/plant (48) was recorded at $40: 40 \mathrm{~kg} \mathrm{~N}: \mathrm{P} / \mathrm{ha}$. The lowest number of pods/plant (35) was recorded in control plot. Similarly in the study areas the number of capsule increases as Nitrogen and Phosphorus increases from 0kg of DAP and UREA (control) to $60 \mathrm{~kg}$ of DAP and $30 \mathrm{~kg}$ of UREA. 
Analysis of variances showed that grain yield, and number of branching per plant was significant differences at $(\mathrm{P}<0.05)$ both at Fadis station and Erersub-station in 2014. Grain yield increases from $525 \mathrm{~kg} / \mathrm{ha}$ to $867.8 \mathrm{~kg} / \mathrm{ha}$ as Nitrogen increases from 0 to $24.6 \mathrm{kgN}(60 \mathrm{kgDAP}$ and $30 \mathrm{kgUREA})$ at Fadis and similarly at Erer grain yield increases from $616.7 \mathrm{~kg} / \mathrm{ha}$ to $912.5 \mathrm{~kg} / \mathrm{ha}$ as Nitrogen increases from 0 to $24.6 \mathrm{kgN}(60 \mathrm{kgDAP}$ and 30kgUREA).This foundation is agreed with the ideas of [12] that indicates maximum yield of seed hectare-1(1.26t) was obtained from $\mathrm{N} 1(60 \mathrm{~kg} / \mathrm{ha})$ whereas the minimum yield of seed per hectare $(0.88 \mathrm{t}$ ) was obtained from N0 (control or without $\mathrm{N})$. N1 (60kg/ha) gave the maximum yield than N2 $(120 \mathrm{~kg} / \mathrm{ha})$ this could be because of excessive nitrogen had been reported to reduce fruit number and yield for sesame but enhances plant growth [13]. As NP increases above the Optimum rate the plant was elongated rather than fruiting and branching. Similarly significant difference was observed on number of branching as Nitrogen and Phosphorus rate increases from 0 to its optimum rate and then decreases above optimum rate because the crop was elongated rather than branching. From the two year (2014 and 2015) and two locations (Fadis and Erer) data; analysis of the variance shows that there was significant difference statically among the treatments because of the application of Nitrogen and Phosphorus rates. Some research findings indicate that sesame cannot respond to fertilizer [10] reported that Number of seeds per pod was similar in the pots that received $\mathrm{N}$ fertilizer and those that did not and also he reported that Number of branches per plants, number of seed per pod, seed yield and dry matter yield were not significantly influenced by Nitrogen fertilizer application.

In the contrast of the above statement from the study areas application of NP to sesame have significant differences among the treatments. Fertilizer studies on sesame, in Ethiopia, are highly limited in scope covering a small proportion of the sesame growing areas in the country. The result of these limited research activities suggested that sesame did not respond to fertilizer addition. But the very recent studies at Bako Agricultural Research Center indicate 35\% yield increment due to application of $38 / 29 \mathrm{~kg} / \mathrm{ha} \mathrm{NP}_{2} \mathrm{O}_{5}$ fertilizers at planting [6]. In the study areas of our finding yield increment were observed on the plot that received $24.6 \mathrm{~kg} / \mathrm{ha}$ of nitrogen and $27.6 \mathrm{~kg} / \mathrm{ha}$ of phosphorus or $\left(60 / 30 \mathrm{~kg} / \mathrm{ha} \mathrm{NP}_{2} \mathrm{O}_{5}\right)$. But some research findings reveal that significance difference was observed by the application NP. [18] reported that grain yield and yield parameters of sesame were significantly enhanced by the application of $40 \mathrm{~kg} \mathrm{~N} \mathrm{ha}^{-1}$ [14]. Showed that phosphorous application at the rate of $22 \mathrm{~kg}$ $P$ ha-1 significantly enhanced seed yield, seed oil content and seed protein content of sesame [15] found that application of $60 \mathrm{~kg} \mathrm{~N} \mathrm{ha}^{-1}$ and $13.2 \mathrm{~kg} \mathrm{P} \mathrm{ha}^{-1}$ produced significantly the highest number of capsules per plant, branches per plant, capsule weight per plant and grain yield per hectare [16]. Recorded the highest sesame seed yield with the application of $60 \mathrm{~kg} \mathrm{~N} \mathrm{ha}^{-1}$ [17] found that application of $75 \mathrm{~kg} \mathrm{~N} \mathrm{ha}^{-1}$ and $26.4 \mathrm{~kg} \mathrm{P} \mathrm{ha}^{-1}$ significantly increased the number of seeds per capsule and seed yield per hectare.

\section{Number of pods/plant}

Analysis of variance showed that number of pods/plant was significantly affected by different levels of nitrogen and phosphorus, while interaction between nitrogen and phosphorus was also found significant. Mean values for nitrogen revealed that maximum numbers of pods/plant (68.67) was noted at $40 / 10 \mathrm{~kg} /$ ha $\mathrm{NP}_{2} \mathrm{O}_{5}$ and minimum number of pods/plant (48.21) was noted at $0 \mathrm{~kg} /$ ha $\mathrm{NP}_{2} \mathrm{O}_{5}$ (control). Number of pods/plant increased with increase in phosphorus levels and minimum number of pods/ plant (48.21) was noted at $0 \mathrm{~kg} \mathrm{P}_{2} \mathrm{O}_{5} / \mathrm{ha}$. The Interaction between nitrogen and phosphorus showed maximum number of pods/ plant (68.67) at 40:10 $\mathrm{kg}_{2} \mathrm{O}_{5}: \mathrm{N} / \mathrm{ha}$, while minimum number of pods/plant (48.21) was recorded at $0: 0 \mathrm{~kg} \mathrm{~N}: \mathrm{P}_{2} \mathrm{O}_{5} /$ ha which is lowest number of pods/plant and recorded in control plot.

\section{Grain yield kg/ha}

Sesame grain yield increased significantly with increase in the rate of nitrogen fertilization, implying that sesame yields could be boosted through an increase in nitrogen fertilizer application [18]. The grain yield of sesame plot-1 (g) was converted into hectare- 1 and has been expressed in kilo grams. The different levels of nitrogen had significant effect on the yield of seed kilo grams ( $\mathrm{kg}$ ) hectare-1. The maximum yield of seed hectare- $1(891 \mathrm{~kg})$ was obtained from T2 $(24.6 \mathrm{~kg} / \mathrm{ha} \mathrm{N})$ or (60DAP@30UREA) whereas the minimum yield of seed per hectare $(518.1 \mathrm{~kg}$ ) was obtained from $\mathrm{T} 1$ (control or without $\mathrm{N}$ ). $\mathrm{T} 7$ (16.4 kg/ha N) gave the maximum yield than T14 (19 kg/ha $\mathrm{N}$ ) this could be because of excessive nitrogen had been reported to reduce fruit number and yield for sesame but enhances plant growth [12]. Similarly this finding agreed with the report of [9] that indicates the highest seed yield $\left(750.4 \mathrm{~kg} \mathrm{ha}^{-1}\right)$ was recorded from the interaction level of 60-30 NPkg ha- 1 and $5 \mathrm{t} \mathrm{ha}^{-1} \mathrm{FYM}$, and the lowest seed yield (480.6 $\mathrm{kg} \mathrm{ha}^{-1}$ ) was recorded from zero level of NP and FYM main factors [18-24].

\section{Conclusion}

In any case before application of fertilizers consider the growth stage of the plant; population; and amount of soil moisture available. Fertilizer applications should be based on soil test results. Since sesame is exported crop most investors are engaged in production and exporting of the commodity in Ethiopia. Now a day because of low quantity of the crop they are diverting to other commodity rather than Sesame. So emphasis should be given for the crop in order to increase the quantity and quality of the commodity through breeding and other agronomic practices. Then research work have incredible role in increasing both the quantity and quality of sesame.

\section{References}

1. MARD (Ministry of Agriculture and Rural Development) (2008) Animal and Plant Health Regulatory Directorate, Crop Register, Issue No. 11. Addis Ababa, Ethiopia. 
2. Central Statistical Agency (2013) Agricultural Sample Survey 2012/2013 (2005 E.C.), Report on Area and Production of Crops (Private Peasant Holdings, Meher Season), Vol. 1.

3. Central Statistical Agency (2008) Agricultural sample survey 2007/08 (2000 E.C.), Vol. 1. Report on area and production of major crops for private peasant holdings, Meher season. Statistical Bulletin 417, Addis Ababa, Ethiopia.

4. Wijnands JHM, Biersteker J, Van Loo EN (2009) Oil seed business opportunity in Ethiopia. Oil seed research report. Addis Ababa, Ethiopia.

5. Wijnands J, Biersteker J, Hiel R (2007) Oil seeds Business Opportunities in Ethiopia. The Hague, Netherlands, pp. 30.

6. Langham DR, Riney J, Smith G, Wiemers T, Peeper D, et al. (2010) Sesame Producer Guide.

7. Ashri A (1994) Genetic resources of sesame: Present and future perspectives. In: Arora RK, Riley KW (Eds.), Sesame Biodiversity in Asia-Conservation, Evaluation and Improvement. IPGRI Office for South Asia, New Delhi, India, pp. 25-39.

8. Kashani S, Buriro M, Nadeem A, Ahmed N, Saeed Z, et al. (2015) Response of Various Sesame Varieties under the Influence of Nitrogen and Phosphorus Doses. AJPS 6(2): 405-412.

9. Kifiriti EM, Deckers J (2001) Sesame, in Crop production in Tropical Africa. In: Rae Mackers RH (Ed.), DGIC Ministry of Foreign Affairs, External Trade \& International Cooperation. Brussels, Belgium, pp. 797- 803.

10. Reddy SR (2004) Principles of Crop Production. Kelyani Publishers, New Delhi, India, p. 649.

11. Shehu EH, Kwari JD, Sandabe MK (2010) Nitrogen, phosphorus and potassium nutrition of sesame (Sesamum indicum L.). New York Sci J 3(12): 21-27.

12. Siddik A, Shirazy BJ, Islam MM, Hoque A (2016) Combined effect of nitrogen and NAA on the yield of Sesame (Sesamum indicum L .) 13(1): 1-9.

13. Aliyu L, Yusuf Y, Ahmed MK (1996) Response of Pepper to Fertilizer: Growth, yield and yield components as affected by nitrogen and phosphorus levels. In: Adebanjo A (Ed.), Proceedings of the $14^{\text {th }}$ HORTSON Conference Ago-Iwoye, Ethiopia, pp. 45-50.
14. Teshome T (2016) Effects of Nitrogen, phosphorous (inorganic fertilizers) and Farm Yard Manure on growth, yield, yield components and oil contents of Sesame (Sesamum indicum L.) at Assosa district, Beneshangul Gumuze Region, Ethiopia. Nature and Science 14(12): 19-28.

15. Olowe VIO, Busari LD (2000) Response of Sesame (Sesamum indicum L.) to Nitrogen and Phosphorous Application in Southern Guinea Savanna of Nigeria. Tropical Oil seed Journal 30-37.

16. Hossein MA, Hamid A, Nasreen S (2007) Effect of nitrogen and phosphorus fertilizer on N/P uptake and yield performance of Groundnut (Arachis hypogea L.). J Agric Res 45(2): 119- 127.

17. Okpara DA, Muoneke CO, Ojikpong TA (2007) Effects of nitrogen and phosphorus fertilizer rates on the growth and yield of sesame (Sesamum indicum $L$ ) in the Southeastern Rainforest Belt of Nigeria. Nigerian Agri J (38): 1-11.

18. Abdel-mottaleb HM, Hafiz SI (2006) Response of canola to some fertilization treatments under sandy soil conditions. Zagazig J Agric Res 33(6): 1025-1041.

19. Abdel-Galil M, Abdel-Ghany REA (2014) Effect of Groundnut Sesame Intercropping and Nitrogen Fertilizer on Yield, Yield Components and Infection of Root- Rot and Wilt Diseases. International Journal of Plant \& Soil Science 3(6): 623-643.

20. Geleta T, Purshotum KS, Wijnand S, Tana T (2007) Integrated management of groundnut root rot using seed quality. International Journal of Pest Management 53(1): 57.

21. Terefe G, Wakjira A, Berhe M, Tadesse H (2012) Sesame Production Manual. Ethiopian Institute of Agricultural Research Embassy of the Kingdom of the Netherlands, EIAR, Ethiopia, p. 49.

22. IAR (Institute of Agricultural Research) (1991) Oilseeds Research and Development in Ethiopia, Proceeding of First National Oilseeds Workshop, Addis Ababa, Ethiopia.

23. Langham DR (2007) Phenology of sesame. In: Janik J, Whipley A (Eds.), Issues in new crops and new uses. ASHS press, Alexandria, Varginia, USA, pp. 144-182.

24. Osman HE (1993) Response of sesame cultivars to plant density and nitrogen in the Sudan central rain lands. Arab Gulf Journal of Scientific Research 11(3): 365-376.

\section{Your next submission with Juniper Publishers} will reach you the below assets

- Quality Editorial service

- Swift Peer Review

- Reprints availability

- E-prints Service

- Manuscript Podcast for convenient understanding

- Global attainment for your research

- Manuscript accessibility in different formats

( Pdf, E-pub, Full Text, Audio)

- Unceasing customer service

Track the below URL for one-step submission https://juniperpublishers.com/online-submission.php 